\title{
NEW AND LITTLE KNOWN SPECIES OF NEARCTIC TRICHOPTERA
}

\author{
By D. G. Denning \\ University of Wyoming, Laramie, Wyoming
}

Examination of additional caddis fly material from western United States has resulted in the recognition of several new and little known species. Descriptions of five of the new species appear in this paper. Unless otherwise stated the types of the new species are in the writers collection at the University of Wyoming. I would like to express my thanks to Dr. L. J. Milne who made available one of his holotypes for comparison with a species illustrated herein.

\section{Leptocella aeolius n. sp.}

This is an interesting species which can readily be differentiated from other described Nearctic Leptocella by the fuscous colored wings. The clasper and tenth tergite are also markedly different from other described species. This species was collected from a clear, cold, rapidly flowing mountain stream at approximately 7,500 feet elevation.

Male.-Forewing length $10 \mathrm{~mm}$. General color of forewings and hindwings reddish brown, considerably brighter toward apex, a series of transverse whitish spots from stigma to apex, fringe along margin near tip of anal veins reddish brown, fringe at apex of hind wing reddish brown.

Genitalia as in fig. 1. Ninth segment with dorsum produced caudad as a concave dorsal hood, below which arises a pair of long finger-like processes; lateral margin produced caudad as a triangular side piece. Tenth tergite practically ventrad in position, wide basally, gradually acuminate, slightly upturned distally, apices narrowly incised for a short distance, fig. 1A; pair of curved filaments which arise near base of tergite expanded at apex into a slightly convex plate. Clasper with basal flap narrow, irregular in outline, neck narrow; mesal lobe subacute 
from lateral aspect, spatulate from dorsal or ventral aspect; lateral apical lobe very irregular and bearing several long stout setae. Between base of claspers arise a pair of filamentous lobes bearing at apex two long slender setae. AEdeagus semi-membranous with characteristic spoonlike ventral plate.

Holotype. Male.-Sybille River, near Wheatland, Wyoming, June 19, 1947 (D. G. Denning).

\section{Athripsodes pfadti n. sp.}

This species is very similar to arielles Denning, but differs from it in details of the tenth tergite, such as the clusters of minute spines along the lateral surface, in the wide sclerotized lobe of the clasper, and the presence of two large internal spines in the aedeagus.

Male.-Length 8-9 mm. Eyes small, separated on dorsum by about five times the dorsal width of one eye. Antennæ rather short, about one and one-third times the length of the forewing; basal portion of each segment white, gradually becoming uniformly brownish. Wings light brown, a prominent white spot at tip of anal veins, a fringe of white hairs along margin, extending from $\mathrm{R}$ to $\mathrm{M}_{3}$. Legs a lighter shade than wings.

Genitalia as in fig. 2. Ninth segment with base wide, considerably narrowed toward center; articulation witb cerci quite indistinct. Cerci, from dorsal aspect, subtriangular, apices separated by a wide triangular incision, a few long fine setæ present. Tenth tergite reaching caudad slightly beyond cerci, apex upturned; viewed from dorsal aspect apical margin straight; lateral surface with two clusters of minute spines, one nearly circular group of six, and one group of three. Clasper with basal portion projected caudad a short distance which appears as a prominant sub-triangular point when viewed from the caudal aspect, fig. $2 \mathrm{~A}$; apical segment semi-membranous, digitate, bearing a scattering of rather stout setæ; sclerotized lobe shorter than apical segment, considerably expanded apically, margin rounded when viewed laterally; somewhat hammer-shaped from caudal view, fig. $2 \mathrm{~A}$, a pair of small setæ along margin; caudal surface of basal 
portion bears several large and small setæ. Adeagus with apical portion semi-membranous, trilobed from lateral view, two prominant spines internally, fig. $2 \mathrm{~B}$.

Female.-Length 6.5-8 mm. Very similar in general characteristics to male. Genitalia as in fig. $2 \mathrm{C}$.

Holotype. Male.-Albany County, Wyoming, Little Laramie River, August 1, 1947 (R. E. Pfadt).

Allotype. Female.-Same data as for holotype.

Paratypes.-17 males, 21 females, same data as for holotype.

\section{Ecclisomyia maculosa Banks}

Originally described from Colorado; very little is known of the distribution of this characteristically western species.

Male.-Length $9 \mathrm{~mm}$. Wings light brown, rather conspicuously irrorate with white markings. Legs a trifle lighter brown than wings, spines black, spurs luteous. Genitalia as in fig. 3 and $3 \mathrm{~A}$.

Female.-Genitalia as in fig. 3B. General characteristics very similar to male. Cercus, from lateral aspect, short and stocky, apex blunt; from dorsal aspect V-shaped incision extends nearly to base ; cerci form a tubular structure with basal portion fused to dorsal portion of tenth segment. Dorsal portion of tenth segment very thin, spatulate, deeply incised, lateral portion also very thin and extending to subgenital plate. Subgenital plate seen from ventral aspect truncate, short and wide, reaching caudad almost to distal margin of dorsal portion of tenth segment.

This species was collected at an elevation of approximately 10,700 feet, along a shallow, narrow swift flowing mountain stream. The majority of the specimens collected were found resting on the banks of the stream, often only an inch or so above the water.

Wyoming: Albany County, Snowy Range Mountains, July 26, 1947 (D. G. Denning) ; 19 males, 3 females.

Limnephilus utahensis $n$. sp.

This species is closely related to occidentalis Banks and labus Ross. It can easily be differentiated from these 
species by the short stocky tenth tergite, the shape of the cerci and claspers and the presence of 3 subapical spines on the lateral arm of the ædeagus.

Male.-Length 14-15 mm. Forewings tawny except for irregular dark brown markings along the veins and a concentration of irregular dark brown markings from the cubitus to the inner margin of the wing. Front femur with a linear patch of black spinules along under side and with 2 small apical spines; front basitarsus subequal to following segment; front tibia with 8 to 10 black spines including one apical pair. Eighth tergite with mesal projection covered with black spinules.

Genitalia as in fig. 4. Ninth segment with lateral portion wide, markedly reduced to a narrow bridge dorsally, portion next to cerci arcuate. Lobes of tenth tergite very short and stocky, apex small and only slightly upturned. Cerci, from lateral view, only a trifle longer than wide, posterior margin slightly sinuate; convergent from dorsal view and with an acute apex; viewed from caudal aspect, fig. 4A, mesal margin black and sharply bent mesad. Claspers longer than wide, sides practically parallel, dorsal and ventral corners rounded, a small acute projection along distal margin. Lateral arms of ædeagus fig. 4B, shorter than main body, apically enlarged into a lobe bearing a brush of fine setæ, apex acute, just caudad to apex occur three small spines as in fig. 4B. Apparently some modification of these subapical spines may occur, as on one lateral arm of the paratype the most ventrad spine is considerably elongated, fig. 4C.

Female.-Length $16 \mathrm{~mm}$. Genitalia as in fig. 4D. Same color and general structure as male. Ninth segment completely divided dorsally. Tenth tergite tubular, apex attenuated, bifid from dorsal view, fig. $4 \mathrm{E}$.

Holotype. Male.-Callao, Juab County, Utah, August 7, 1945 (G. F. Knowlton), at light. [U. S. National Museum Collection.]

Allotype. Female.-Same data as for holotype.

Paratype. Male. Same data as for holotype.

Holotype and allotype deposited in the U. S. National Museum. 
Dr. G. F. Knowlton collected these specimens from a light trap operated near a small pond fed from an artesian well. Callao is located just southwest of the Great Salt Lake Desert.

Lepidostoma veleda $n$. sp.

This species belongs to the Pluvial group and bears closest resemblance to ormea Ross and rayneri Ross. It can be distinguished from these species by the lateral lobe of the tenth tergite which bears a dorsal and ventral spine opposite one another and the short truncate condition of the tenth tergite when seen from the dorsal aspect.

Male.-Length 7.5-8 mm. Basal segment of antenna long, almost equal to dorsal width of head, a scattering of black scales over most of segment, especially dense along mesal surface. Third segment of maxillary palpus with a very dense brush of long black scales. Costal cells of forewing reflexed nearly to media, resultant pocket lined with dense brown setæ and black scales which are especially heavy along margin, in a few individuals a scattering of black scales will be found extending beyond margin of pocket.

Genitalia as in fig. 5. Ninth segment annular, tergite produced into a triangular projection. Tenth tergite divided into a pair of divergent lateral lobes, separated on meson to base, from dorsal aspect, fig. 5A, short, truncate, prominent acute dorsal spine near center of margin; from lateral aspect, fig. 5, dorsal spine directed dorsad, in a straight line with the ventral spine which is curved slightly cephalad. Claspers long, narrow, convergent from ventral view, at base the short digitate process is gradually curved caudad, apex sub-acute with small acute caudad directed process near apex on mesal surface. Adeagus long, tubular, base bulbous, apex of main portion submembranous and with a pair of long, slender, acute tubular processes along dorsal surface.

Female.-Length 8-8.5 mm. Similar to male except for sexual dimorphic characters. Ninth and tenth tergites, fig. 5B, relatively short; ninth tergite becomes a darkened sub-acute angulation at apex, the tenth tergite lobes divided and broadly rounded at apex. Spermatheca, fig. 
$5 \mathrm{C}$, with ventral bridge well marked and crossing spermatheca near margin.

Holotype. Male.-Albany County, Wyoming, Snowy Range Mountains, near Centennial, Wyoming, August 3, 1947 (D. G. Denning).

Allotype. Female.-Same data as for holotype.

Paratypes. - 5 males, 2 females ; Woods Landing, Wyoming, August 10, 1947 (D. G. Denning). 3 males; Poudre River, 15 miles west of Teds Place, Colorado, August 17, 1947 (D. G. Denning). 3 males, 4 females ; Poudre River, approximately 15 miles east of Cameron Pass, Colorado, August 19, 1947 (D. G. Denning). 10 males ; Rocky Mountain National Park, Colorado, August 9, 1947 (D. G. Denning).

In all instances the species was collected only from clear, swift flowing mountain streams.

\section{Lepidostoma ormea Ross}

This recently described species was previously known only from a male collected in Utah.

Colorado: Illinois River, south of Walden; August 10, 1947 (D. G. Denning), 1 male.

Collected from a shallow, clear swift flowing stream at approximately 8,000 feet elevation.

\section{Rhyacophila mirus n. sp.}

This species is very closely related to alberta Banks.

Male.-Length 11-12 mm. Color brownish yellow, with a scattering of dark brown markings over most of forewing. First and second pair of legs light brown except for a light yellowish color over apical portion of tibia, third pair of legs luteous. Sternum of sixth and seventh segment with a short acute mesal projection.

Genitalia as in fig. 6 . Ninth segment with a wide emargination laterally resulting in the ventral half being greatly narrowed. Tenth tergite declivous from lateral view, reaching ventrad to margin of clasper ; from dorsal aspect, fig. $6 \mathrm{~A}$, slender, practically same width throughout, apical portion produced into a pair of thin plates, the inner pair (best viewed from lateral aspect) slender and 
rounded distally, the outer pair convex, wide and distally nearly truncate. Basal segment of clasper long, almost two and one-half times as long as wide, margins nearly parallel; apical segment about one-half as long, the ventral margin attenuated as in fig. 6. Adeagus long, reaching to caudal margin of basal segment of clasper, apical half of exposed portion slender, tubular, apex bifid; lateral arms from ventral aspect, fig. 6B, reaching caudad one-third length of apical segment of clasper, apices gradually convergent, near middle of lateral arms area is expanded, its ventral surface bearing a number of minute spicules and its margin bearing a series of seven flat setæ.

Female.-Length $12 \mathrm{~mm}$. Same general color and characteristics as for male. Sixth sternum with an acute mesal projection. Eighth sternum with a wide mesal projection. Genitalia simple, tubular and tapering from base to apex.

Holotype. Male.-Albany County, Wyoming, Snowy Range Mountains, outlet of Mill Pond; September 25, 1947 (D. G. Denning).

Allotype. Female.-Same data as for holotype.

Paratypes. Same data as for holotype, except August 31, 1947, 2 males.

All specimens collected from a clear, cold, swift-flowing mountain stream at approximately 10,500 feet elevation.

Rhyacophila verrula Milne

The collecting of this species in southeastern Wyoming constitutes a considerable extension to its previously known range of British Columbia, Alberta, Oregon and Washington. Male genitalia, fig. 7, drawn from a specimen compared to holotype.

Wyoming: Snowy Range Mountains, outlet of Lake Marie; August 31, 1947 (D. G. Denning), 3 males, 1 female. Collected along a rapid mountain stream at 10,500 feet elevation. Albany County, Snowy Range Mountains, outlet of Mill Pond; September 25, 1947 (D. G. Denning), 1 male. Collected along a rapid mountain stream at 10,500 feet elevation. Albany County, Snowy Range Mountains, Nash Fork Creek; September 25, 1947 (D. G. 
Denning), 3 males. Collected along a rapid mountain stream at 9,600 feet elevation.

\section{Polycentropus halidus Milne}

This species has not been recorded since it was described in 1936 by Milne from New Mexico. The determination of the specimen used in the illustration, fig. 8, was checked by Ross.

California: Morgan Hill; September 5, 1939 (C. E. Mickel), at light, 2 males, 1 female.

Arizona: Oak Creek Canyon, Banjo Bill Forest Camp; June, 1942 (C. P. Alexander), 2 males.

\section{Polycentropus variegatus (Banks)}

Very little is known regarding the distribution of this species previously recorded from Washington and British Columbia. The collecting of the species in southeastern Wyoming is a very interesting extension in its known range. Male genitalia as in fig. 9 .

British Columbia: Cowichan Lake, August 1940 (C. P. Idyll), 2 males.

Wyoming: Pole Mountain, near Laramie; August 16, 1947 (D. G. Denning), 1 male. Collected along a clear, shallow mountain stream at approximately 7,500 feet elevation.

California: Lake Tahoe; August 20, 1916 (L. Bruner), 1 male, 1 female. 


\section{Explanation of Plate 3}

Fig. 1. Leptocella aolius, lateral aspect; 1A, tenth tergite, ventral aspect. Fig. 2. Athripsodes pfadti, lateral aspect; 2A, clasper, caudal aspect; $2 \mathrm{~B}$, ædeagus, lateral aspect; 2C, lateral aspect of female.

Fig. 3. Ecclisomyia maculosa lateral aspect; 3A, ventral aspect; 3B, lateral aspect of female.

Fig. 4. Limnephilus utahensis, lateral aspect; 4A, margin of claspers, caudal aspect; 4B, lateral arm of ædeagus; 4C, apex of lateral arm of ædeagus of paratype; $4 \mathrm{D}$, lateral aspect of female; $4 \mathrm{E}$, dorsal aspect of tenth tergite of female. 


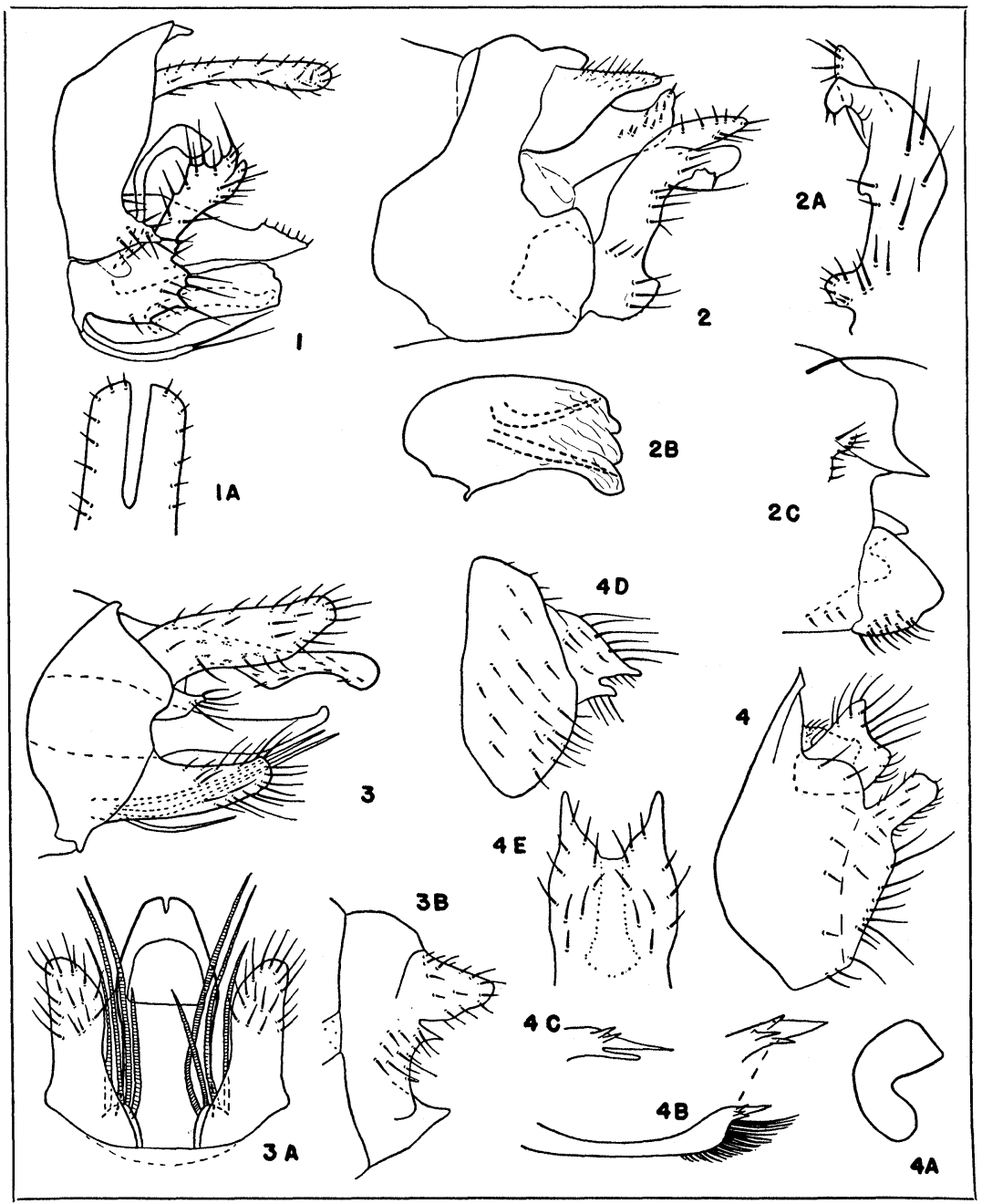

Denning-Nearctic Trichoptera 


\section{Explanation of Plate 4}

Fig. 5. Lepidostoma veleda, lateral aspect; 5A, dorsal aspect of tenth tergite; 5B, lateral aspect of female; $5 \mathrm{C}$, spermatheca.

Fig. 6. Rhyacophila mirus, lateral aspect; 6A, dorsal aspect of tenth tergite; $6 \mathrm{~B}$, ventral aspect of ædeagus and lateral arms.

Fig. 7. Rhyacophila verrula, lateral aspect; $7 \mathrm{~A}$, sheath of ædeagus from ventral aspect; 7B, dorsal aspect of ninth and tenth tergites.

Fig. 8. Polycentropus halidus, lateral aspect.

Fig. 9. Polycentropus variegatus, lateral aspect; $9 \mathrm{~A}$, lateral aspect of ædeagus. 


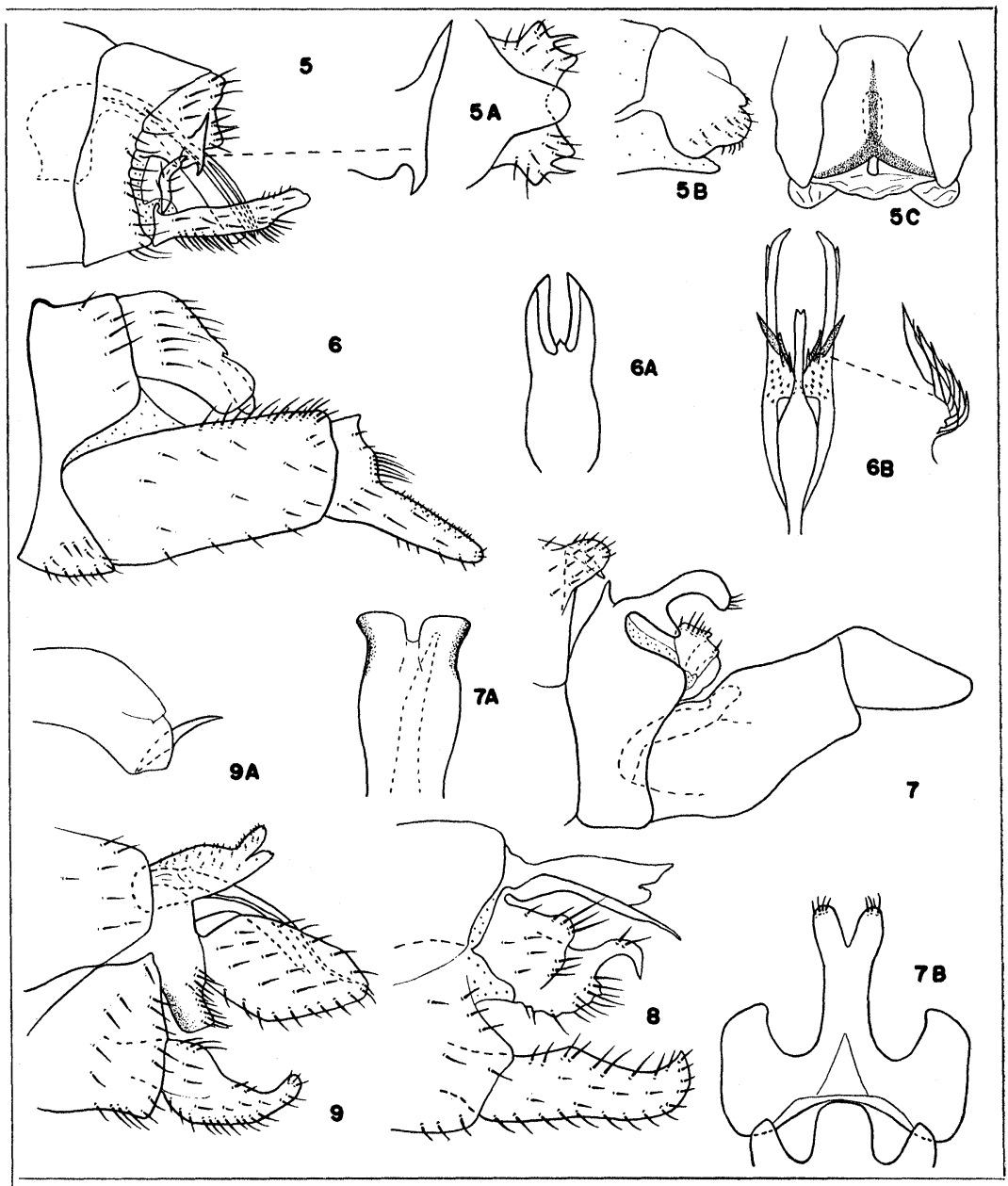

DenNing-NearCtic Trichoptera 

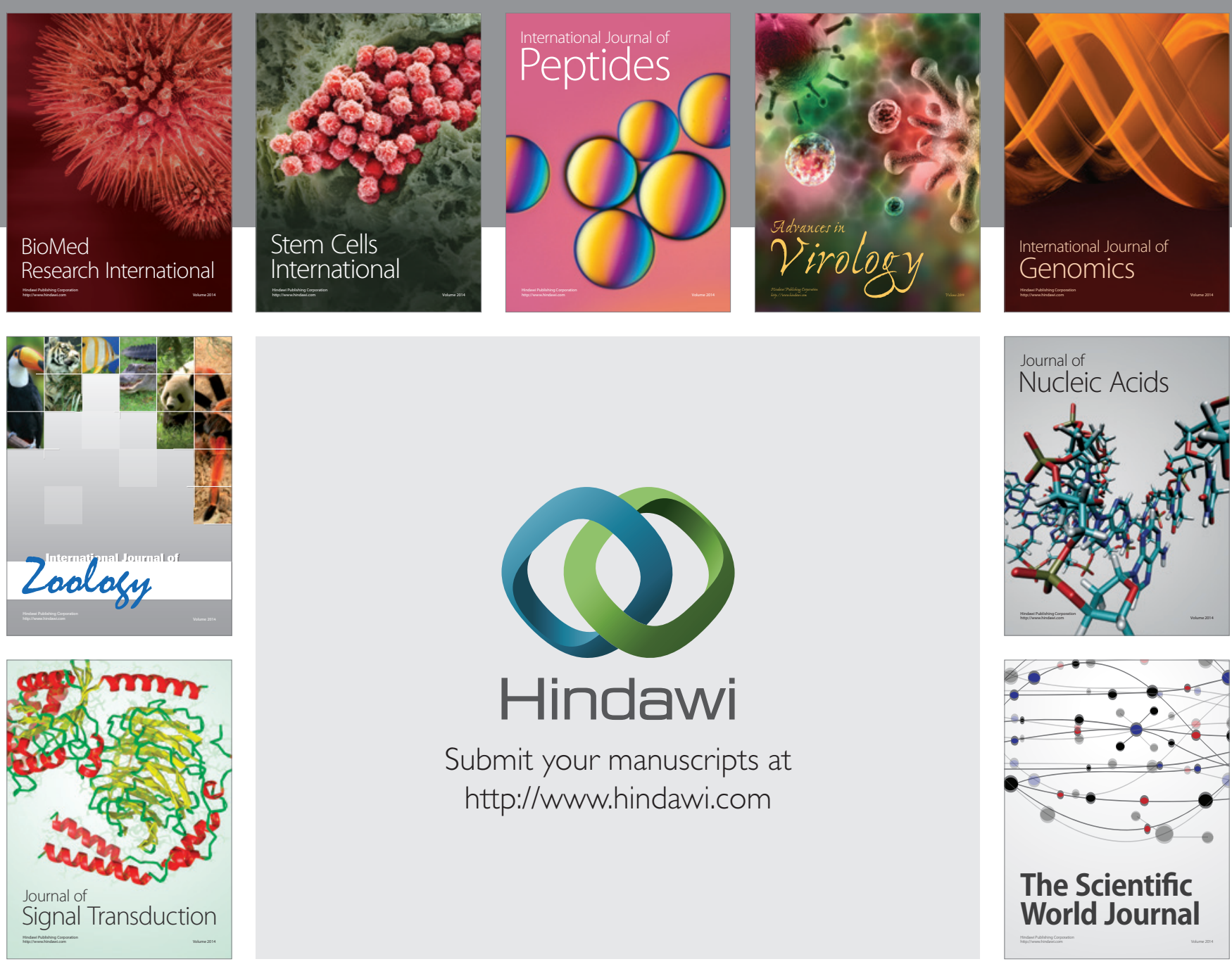

Submit your manuscripts at

http://www.hindawi.com
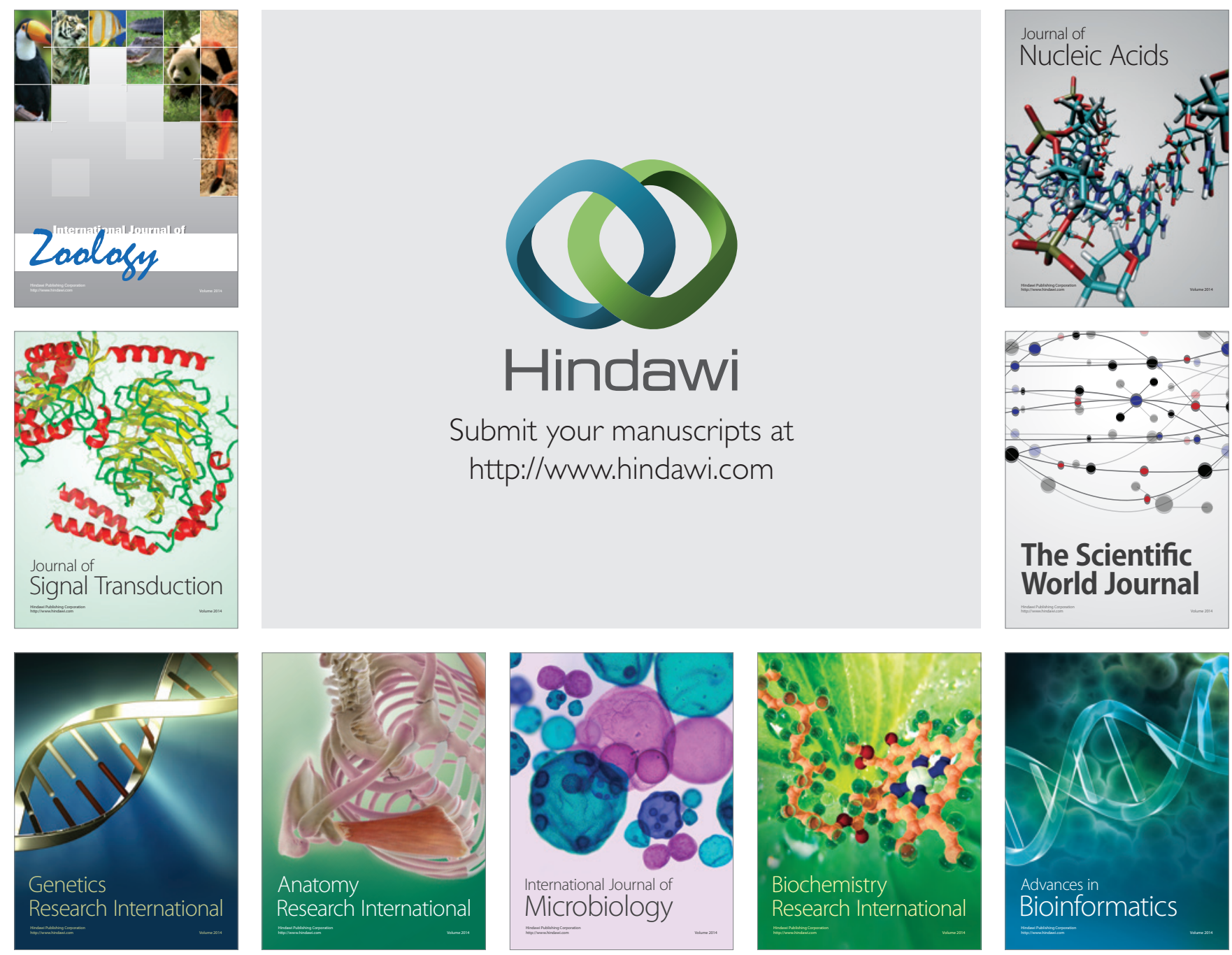

The Scientific World Journal
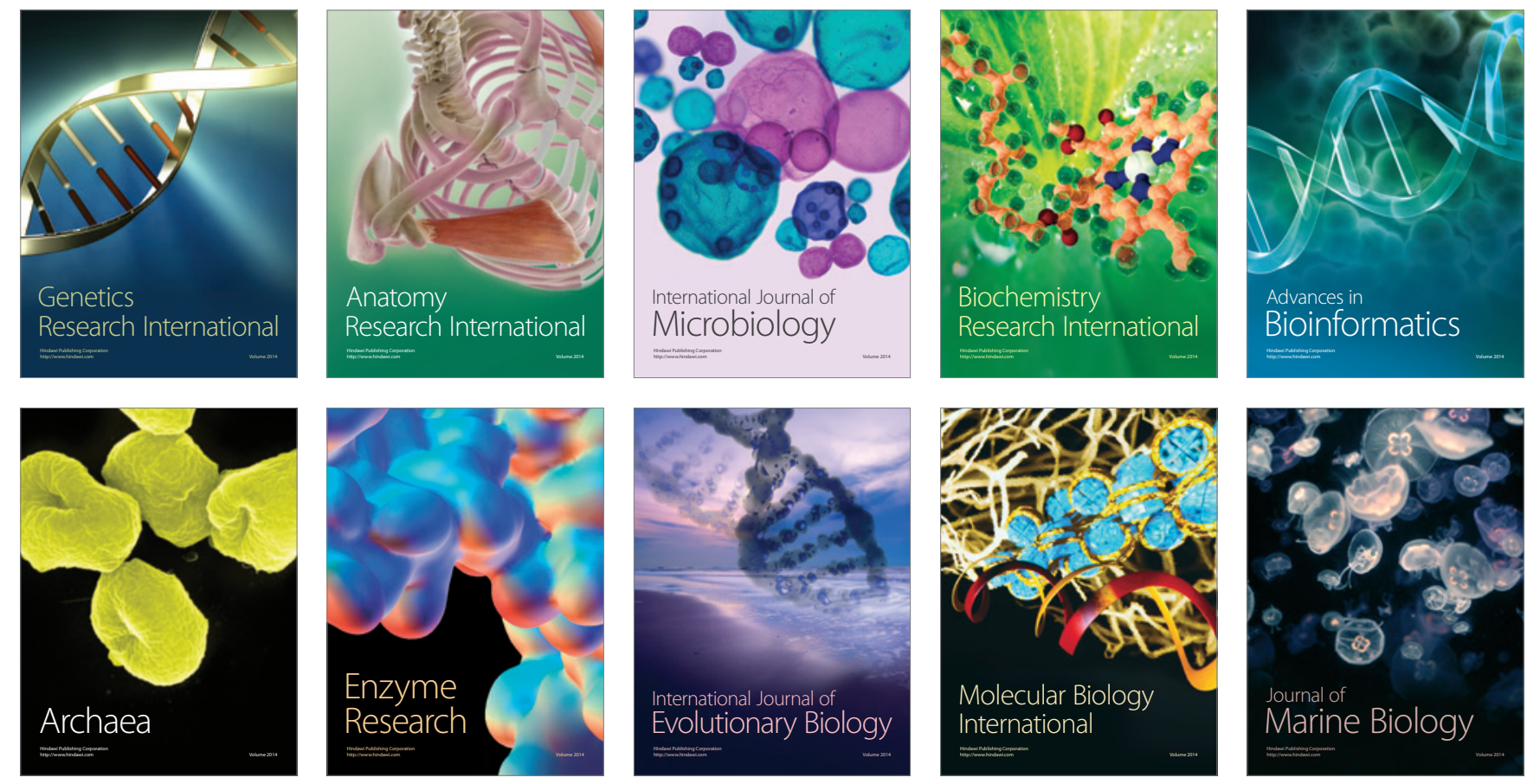